\author{
Т. Г. Фесенко ${ }^{1}$, к.т.н., доиент, \\ професор кафедри будівництва та архітектури, \\ e-mail: fesenkotatyana@gmail.com \\ Мохамед Абдулсалам Сіск Алі ${ }^{2}$, аспірант \\ ${ }^{1}$ Луганський національний аграрний університет, \\ вул. Алчевських, 44, м. Харків, 61002, Україна \\ ${ }^{2}$ Вищий навчальний заклад "Університет економіки та права "КРОК”, \\ вул. Табірна, 30-32, м. Київ, 03113, Україна

\section{МОДЕЛЮВАННЯ ОЦІНКИ “RISK MANAGEMENT" В СИСТЕМІ УПРАВЛІННЯ БУДІВЕЛЬНИМИ ПРОЕКТАМИ}

Окреслено базові прочеси, методи та інструменти управління ризиками проектів в системі знань Guide to the Project Management Body of Knowledge. Проаналізовано теоретикопрактичні підходи до управління ризиковими подіями, щуо впливають на вартість, терміни, якість виконання будівельних проектів. Запропоновано виокремлення ризик-компонентів як вагомої складової технологічної зрілості компанії-забудовника в управлінні будівельними проектами. Розроблено модель оцінки зрілості ризик-менеджменту в контексті розвитку управління ризиками будівельних проектів. Представлено математичний опис для оиінки п'яти рівнів зрілості ризик-менеджменту. Запропонований інструмент оиінювання може бути застосований дирекиіями і топ-менеджментом будівельних та девелоперських компаній для проведення самооиінки прогресу у розвитку проектно-орієнтованого управління, а також вибору дій, необхідних для переходу на вищий рівень зрілості.

Ключові слова: зрілість ризик-менеджменту, управління будівельними проектами, компанія-забудовник.

Постановка проблеми. На сьогодні проектний менеджмент застосовується для організаційно-технічного забезпечення системи управління будівельними проектами та дозволяє суттєво посилювати іiі потенціал, отримувати синергетичний ефект. У методології проектного менеджменту представлені підходи, моделі, інструменти для постійного організаційного удосконалення (проектноорієнтованого зростання). Втім, питання практичного їх застосування для конкретної галузі залишаються актуальними, у тому числі через існуючі ризики.

Ризик-менеджмент $\epsilon$ критично важливою складовою управління будівельними проектами, особливо в умовах турбулентного проектного середовища. Зокрема, в Україні часто спостерігаються симптоми низької керованості будівельних проектів: значна кількість об'єктів вводиться в експлуатацію 3 перевищенням запланованого терміну, бюджету тощо. Крім того існують ризики, пов'язані із удосконаленням самої системи проектного менеджменту.
Аналіз останніх досліджень. Управління ризиками проектів окреслено системою знань Guide to the Project Management Body of Knowledge (РМВОК) [1] і представлено сімома процесами:

1. Планування управління ризиками процес визначення, яким чином буде здійснюватись управління ризиками в проекті.

2. Ідентифікаиія ризиків - процес визначення переліку ризиків, які можуть впливати на проект, а також документування їх характеристик (здатність команди проекту передбачати можливі ризикові події).

3. Якісний аналіз ризиків - процес встановлення пріоритетів ризиків 3 метою подальшого їх аналізу, оцінки вірогідності виникнення та розробки дій впливу.

4. Кількісний аналіз ризиків - процес кількісного аналізу впливу ідентифікованих ризиків на цілі проекту у цілому.

5. Планування реагування на ризики процес розробки варіантів дій щодо розширення сприятливих можливостей для скорочення загроз цілям проекту.

6. Імплементачія впливу на ризики процес підтвердження що діі//заходи реагу- 
вання на ризики виконуються відповідно до плану.

7. Моніторинг ризиків - процес моніторингу виконання планів реагування на ризики, відстеження виявлених ризиків, ідентифікація та аналіз нових ризиків, оцінка управління ризиками протягом усього проекту.

Ефективне виконання процесів управління ризиками передбачає 15 видів “інструментів та методів” (табл. 1).

Таблиця 1

Матриця кореляції процесів управління ризиками 3 “інструментами та методами" їх реалізації

\begin{tabular}{|c|c|c|c|c|c|c|c|c|c|c|c|c|c|c|c|}
\hline \multirow[b]{2}{*}{$\begin{array}{c}\text { Процеси } \\
\text { управління } \\
\text { ризиками } \\
\text { проектів }\end{array}$} & \multirow[b]{2}{*}{ 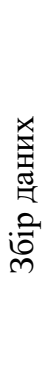 } & \multirow[b]{2}{*}{ 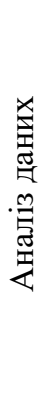 } & \multirow[b]{2}{*}{ 突 } & \multicolumn{4}{|c|}{ Стратегії } & \multirow[b]{2}{*}{ 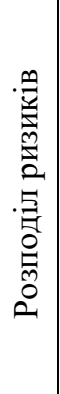 } & \multirow[b]{2}{*}{ 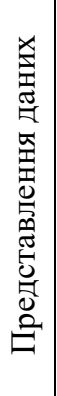 } & \multirow[b]{2}{*}{ 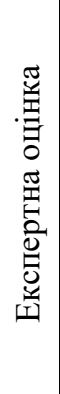 } & \multirow[b]{2}{*}{ 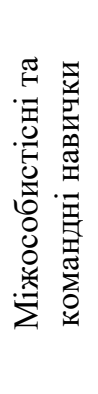 } & \multirow[b]{2}{*}{ 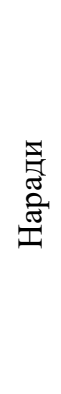 } & \multirow{2}{*}{ 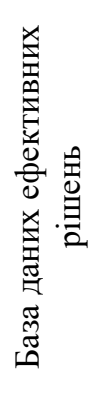 } & \multirow[b]{2}{*}{ 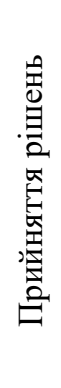 } & \multirow[b]{2}{*}{ 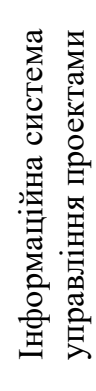 } \\
\hline & & & & 莒 & 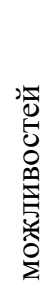 & 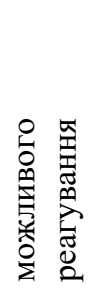 & 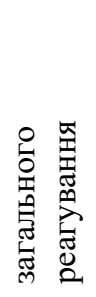 & & & & & & & & \\
\hline $\begin{array}{c}\text { 1. Планування } \\
\text { управління } \\
\text { ризиками }\end{array}$ & & $X$ & & & & & & & & $X$ & & $X$ & & & \\
\hline $\begin{array}{l}\text { 2. Ідентифікація } \\
\text { ризиків }\end{array}$ & $\mathrm{X}$ & $\mathrm{X}$ & & & & & & & & $\mathrm{X}$ & $\mathrm{X}$ & $\mathrm{X}$ & $\mathrm{X}$ & & \\
\hline $\begin{array}{l}\text { 3. Якісний аналіз } \\
\text { ризиків }\end{array}$ & $\mathrm{X}$ & $\mathrm{X}$ & & & & & & $\mathrm{X}$ & $X$ & $\mathrm{X}$ & $\mathrm{X}$ & $\mathrm{X}$ & & & \\
\hline $\begin{array}{l}\text { 4. Кількісний } \\
\text { аналіз ризиків }\end{array}$ & $X$ & $\mathrm{X}$ & & & & & & & & $X$ & $X$ & $X$ & & & \\
\hline $\begin{array}{c}\text { 5. Планування } \\
\text { реагування } \\
\text { на ризики }\end{array}$ & $\mathrm{X}$ & $\mathrm{X}$ & & $\mathrm{X}$ & $\mathrm{X}$ & $\mathrm{X}$ & $\mathrm{X}$ & & & $\mathrm{X}$ & $\mathrm{X}$ & & & $\mathrm{X}$ & \\
\hline $\begin{array}{l}\text { 6. Імплементація } \\
\text { впливу на ризики }\end{array}$ & & & & & & & & & & $\mathrm{X}$ & $\mathrm{X}$ & & & & $X$ \\
\hline $\begin{array}{l}\text { 7. Моніторинг } \\
\text { ризиків }\end{array}$ & & $\mathrm{X}$ & $\mathrm{X}$ & & & & & & & & & $X$ & & & \\
\hline
\end{tabular}

X-методи та інструменти, які застосовуються для реалізації процесу

Управлінню ризиками в будівельних проектах присвячено дослідження [2-7], автори яких акцентують увагу на окремі області знань управління проектами.

Зокрема, у роботах [2-3] розглядаються фінансові ризики інвестиційно-будівельних проектів та враховується функціональне призначення будівлі. Так, зменшення ризиків по вкладених інвестиціях у проекти житлового будівництва найбільш оптимальним вбачається шляхом застосування фондів фінансування будівництва та випуск безпроцентних (цільових) облігацій забудовниками [2]. Для удосконалення управління бюджетними ризиками проектів будівництва складних енергетичних об'єктів авторами роботи [3] запропоновано "протиризиковий метод управління бюджетуванням", що передбачає створення фі- нансових та інформаційних резервів 3 періодичним проведенням аналізу "план-факт" та перерахунку бюджету.

Автори робіт [4-5] досліджують ризикові події, що впливають на терміни виконання будівельних робіт. Для усунення ризиків зриву термінів реалізації будівельних проектів пропонується в методиці розрахунку ризиків шляхом вводити показник виробітку працівників у минулих періодах [4], а також застосовувати нечітку логіку на етапі розробки календарного плану [5].

Управління ризикованими подіями, які пов'язані зі якістю та змістом будівельного проекту, автори [6-7] пропонують розглядати в контексті “надійності". Також дослідники аналізують управління ризиками в контексті формування портфеля інвестиційно- 
будівельних проектів [8], творчого підходу команди для управління девелоперського проекту [9].

Разом 3 тим, відмічається значимість ризик-менеджменту для організаційного розвитку компаній [10]. Слід зазначити, що базові параметри ризик-менеджменту у проектній діяльності окреслені у моделі зрілого управління проектами Project Management Maturity Model (PMMM) [11].

Для того, щоб управління будівельними проектами якісно покращило свою організаційно-технічну систему, необхідно сформувати реальну підтримку вищого керівництва i виконавців та запровадити у роботу команди проекту інструменти/засоби розвитку зрілості ризик-менеджменту компанії забудовника.

Метою даної роботи $є$ розробка рішення щодо оцінки зрілості системи управління будівельними проектами (компаніізабудовника) в контексті Risk Management.

Виклад основного матеріалу. У моделі РМММ визначені ризик-контексти для кожного із п'яти рівнів зрілості проектного менеджменту:

на рівні 1 - термінологія - ризики (середнього ступеня) розглядаються у контексті можливих проявів “опору” змінам в організаційній структурі та повноваженнях команди проекту;

на рівні 2 - загальні процеси - ризики (середнього ступеня) розглядаються у залежності від підтримки керівництва у розробці методології управління ризиками в проектах, опору змінам (ризиковим подіям), створення сталої корпоративної культури;

на рівні 3 - єдина методологія - управління проектами здійснюється в умовах “високих" ризиків. Розглядаються ситуації, коли під час запровадження єдиних стандартів проектного менеджменту для усієї компанії можуть виникати "слабкі місця" на рівні окремих організаційно-технічних структур;

на рівні 4 - бенчмаркінг - відбувається удосконалення процесів, процедур, операцій, моделей, методик й інструментів проектної діяльності. Формуються також умови для створення продукту проекту високої якості, унікальності, оптимальними ресурсами. Така ситуація характеризується “низьким” ризиком;

на рівні 5 - безперервне удосконалення - організація оцінює інформацію, отриману під час бенчмаркінгу, i приймає рішення про те, чи буде ця інформація включена до єдиної методології. Цей рівень також маркується як “низько-ризиковий”.

Визначення зрілості "Risk Management” в системі управління будівельними проектами (компанії-забудовника) грунтується на оцінці рівня наявності характеристик управління ризиками (табл. 2). Пропонується наступна шкала оцінювання: «1» - відповідність критерію в повній мірі; «0» - невідповідність критерію (критерій відсутній); «-1» - критерій має значну регресійну тенденцію.

Таблиця 2

Оцінка зрілості “Risk Management” в системі управління будівельними проектами (компанії-забудовника)

\begin{tabular}{|c|c|}
\hline $\begin{array}{c}\text { Рівні } \\
\text { зрілості }\end{array}$ & Характеристика зрілості "Risk Management" \\
\hline $\begin{array}{c}\text { Рівень I: } \\
\text { Термінологія }\end{array}$ & 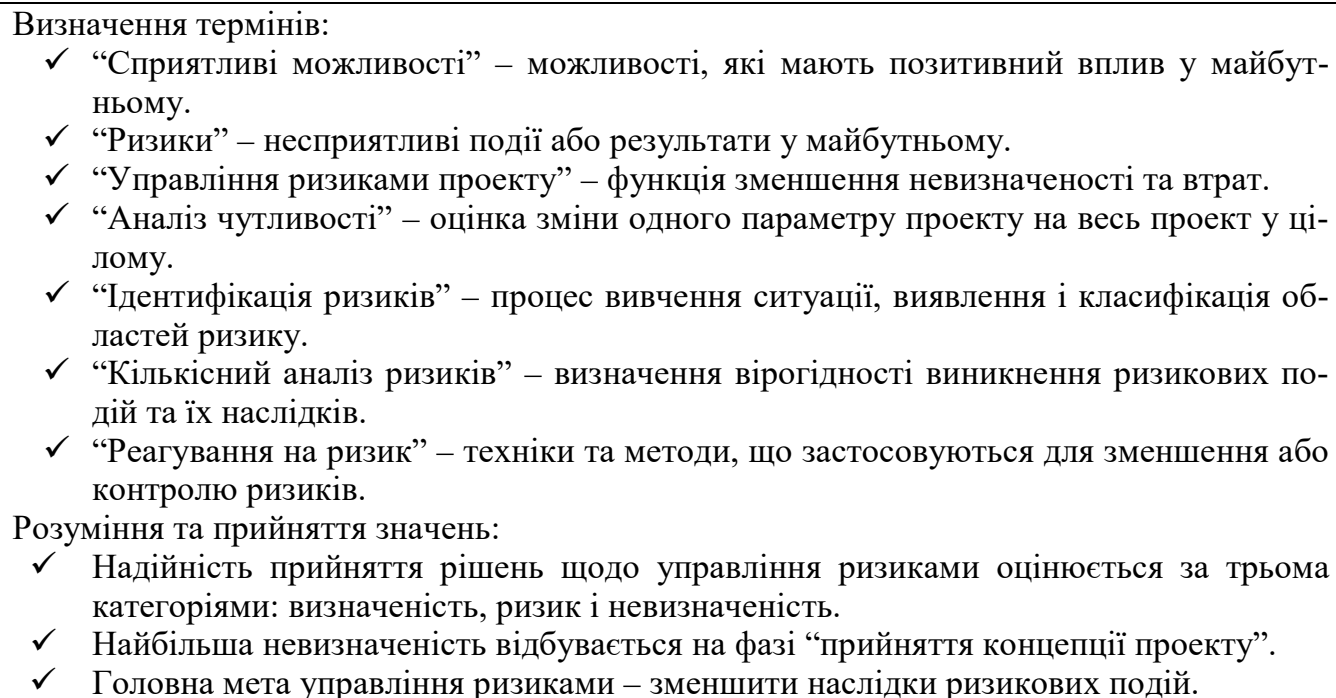 \\
\hline
\end{tabular}


Продовження табл. 2

\begin{tabular}{|c|c|}
\hline $\begin{array}{c}\text { Рівні } \\
\text { зрілості }\end{array}$ & Характеристика зрілості "Risk Management" \\
\hline $\begin{array}{l}\text { Рівень II: } \\
\text { Загальні } \\
\text { процеси }\end{array}$ & $\begin{aligned} \text { Визнання вигід від реалізації та удосконалення процесів управління ризиками: } \\
\text { - } \quad \text { планування управління ризиками; } \\
\text { - } \quad \text { ідентифікація ризиків; } \\
\text { - } \quad \text { якісний аналіз ризиків; } \\
-\quad \text { кількісний аналіз ризиків; } \\
\text { - } \quad \text { планування реагування на ризики } \\
\text { - } \quad \text { імплементація впливу на ризики; } \\
\text { - } \quad \text { моніторинг ризиків. }\end{aligned}$ \\
\hline $\begin{array}{c}\text { Рівень III: } \\
\text { Сдина мето- } \\
\text { дологія }\end{array}$ & $\begin{array}{l}\text { 3.1. Застосування процесів управління ризиками здійснюється паралельно з інжинірин- } \\
\text { гом та загальним управлінням якістю. } \\
\text { 3.2. Усі проекти ведуться із застосуванням “інструментів та методів” управління ризи- } \\
\text { ками (табл. 1). } \\
\text { 3.3. Процес управління ризиками в компанії-забудовника здійснюється з урахуванням } \\
\text { фінансових, технічних та тимчасових ризиків. } \\
\text { 3.4. Методологія управління ризиками в компанії-забудовника заснована на структур- } \\
\text { ній методології, що підтримується на політиці, процедурах і стандартних формах для } \\
\text { заповнення. } \\
\text { 3.5. Для компанії-забудовника найбільш важливими є навички інтеграції та управління } \\
\text { ризиками. } \\
\text { 3.6. Заохочення менеджерів проектів за прийняття “ризикових рішень” }\end{array}$ \\
\hline $\begin{array}{c}\text { Рівень IV: } \\
\text { Бенчмаркінг }\end{array}$ & $\begin{array}{l}\text { 4.1. Під час бенчмаркінгу виявлено, що для удосконалення управління ризиками необ- } \\
\text { хідна більша деталізація/декомпозиція ієрархічної структури робіт. } \\
\text { 4.2. Під час бенчмаркінгу досліджується, яким чином інші компанії-забудовники залу- } \\
\text { чають своїх клієнтів (користувачів) до управління ризиками будівельного проекту. } \\
\text { 4.3. Під час бенчмаркінгу досліджується, яким чином інші компанї̈-забудовники залу- } \\
\text { чають своїх працівників до прийняття та застосування єдиної методології управління } \\
\text { ризиками будівельних проектів, збільшуючи їх ефективність. } \\
\text { 4.4. Під час бенчмаркінгу досліджується, яким чином інші компанії-забудовники } \\
\text { управляють технічними ризиками. } \\
\text { 4.5. Під час бенчмаркінгу досліджується, яким чином інші компанії-забудовники здійс- } \\
\text { нюють “інструменти та методи” управління ризиками (табл. 1) в процесі паралельного } \\
\text { інжинірингу. }\end{array}$ \\
\hline $\begin{array}{c}\text { Рівень V: } \\
\text { Безперервне } \\
\text { удоскона- } \\
\text { лення }\end{array}$ & $\begin{array}{l}\text { 5.1. Удосконалення методології управління ризиками дозволяє компанії-забудовнику } \\
\text { підвищити рівень клієнт-орієнтованості []. } \\
\text { 5.2. Удосконалення програмного забезпечення для управління ризиками будівельних } \\
\text { проектів. } \\
\text { 5.3. Зміни умов роботи (залежно від специфіки об’єкту будівництва) забезпечу- } \\
\text { ють/підвищують раціональність методології ризик-менеджменту. } \\
\text { 5.4. Зміни у взаємодії із клієнтами, користувачами приводять до змін в управлінні ризи- } \\
\text { ками проекту. } \\
\text { 5.5. У зв’язку зі змінами вимог будівельних проектів змінюються й “інструменти та } \\
\text { методи” управління ризиками (табл. 1). }\end{array}$ \\
\hline
\end{tabular}

Цільова функція, що описує зрілість "Risk Management" в системі управління будівельними проектами (компанії-забудовника), набуває вигляду (1)-(10):

$$
\begin{gathered}
\Delta B_{R M}=\sum_{d}^{d^{\prime}} \sum_{i}^{i^{\prime}} \sum_{u}^{u^{\prime}} \sum_{j}^{j^{\prime}} \sum_{n}^{n^{\prime}} \sum_{m}^{m^{\prime}} \sum_{a}^{a \prime} \sum_{z}^{z^{\prime}} \sum_{g}^{g^{\prime}}\left(I_{d}+\right. \\
+S_{i}+T_{u}+C_{j}+Q_{n}+R_{m}+M_{a}+ \\
\left.+P_{z}+H_{g}\right) \rightarrow \text { opt }
\end{gathered}
$$

$$
\begin{gathered}
I=\left\{I_{1}, I_{2}, \ldots, I_{d}\right\}, d=\overline{1, d^{\prime}}, \\
S=\left\{S_{1}, S_{2}, \ldots, S_{i}\right\}, i=\overline{1, \iota^{\prime}}, \\
T=\left\{T_{1}, T_{2}, \ldots, T_{u}\right\}, u=\overline{1, u^{\prime}}, \\
C=\left\{C_{1}, C_{2}, \ldots, C_{j}\right\}, j=\overline{1, J^{\prime}}, \\
Q=\left\{Q_{1}, Q_{2}, \ldots, Q_{n}\right\}, n=\overline{1, n^{\prime}}, \\
R=\left\{R_{1}, R_{2}, \ldots, R_{m}\right\}, m=\overline{1, m^{\prime}},
\end{gathered}
$$




$$
\begin{gathered}
M=\left\{M_{1}, M_{2}, \ldots, M_{a}\right\}, a=\overline{1, a^{\prime}}, \\
P=\left\{P_{1}, P_{2}, \ldots, P_{z}\right\}, z=\overline{1, z^{\prime}}, \\
H=\left\{H_{1}, H_{2}, \ldots, H_{g}\right\}, g=\overline{1, g^{\prime}},
\end{gathered}
$$

де $I_{d}-$ оцінка управління ризиками, пов'язаними з інтеграцією будівельних проектів, $d$ - кількісна оцінка здатності компаніїзабудовника (B) управляти ризиками, пов'язаними з інтеграцією проектів, $d=\overline{1 ; d^{\prime}}$, $d^{\prime}$ - експертна бальна оцінка компаніїзабудовника управляти ризиками, пов'язаними 3 інтеграцією будівельних проектів;

$S_{i}$ - оцінка управління ризиками, пов'язаними зі змістом будівельних проектів, i - кількісна оцінка здатності компаніїзабудовника управляти ризиками, пов'язаними зі змістом проектів, $i=\overline{1 ; l^{\prime}}, i^{\prime}-$ експертна бальна оцінка компаніїзабудовника управляти ризиками, пов'язаними зі змістом будівельних проектів;

$T_{u}$ - оцінка управління ризиками, пов'язаними 3 розкладом будівельних проектів, $и$ - кількісна оцінка здатності компаніїзабудовника управляти розкладом проектів, $u=\overline{1 ; u}, u^{\prime}-$ експертна бальна оцінка компанії-забудовника управляти ризиками, пов'язаними 3 розкладом будівельних проектів;

$C_{j}$ - оцінка управління ризиками, пов'язаними з вартістю будівельних проектів, $j$ - кількісна оцінка здатності компаніїзабудовника управляти ризиками, пов'язаними з вартістю проектів, $j=\overline{1 ; \jmath}, j^{\prime}-$ експертна бальна оцінка компаніїзабудовника управляти ризиками, пов'язаними з вартістю будівельних проектів;

$Q_{n}$ - оцінка управління ризиками, пов'язаними 3 якістю будівельних проектів, $n$ - кількісна оцінка здатності компаніїзабудовника управляти ризиками, пов'язаними 3 якістю, $n=\overline{1 ; n}, n^{\prime}-$ експертна бальна оцінка компанії-забудовника управляти ризиками, пов'язаними 3 якістю будівельних проектів;

$R_{m}$ - оцінка управління ризиками, пов'язаними 3 ресурсами будівельних проектів, $m$ - кількісна оцінка здатності компаніїзабудовника управляти ризиками, пов'язаними $з$ ресурсами проектів, $m=\overline{1 ; m}$ ', $m^{\prime}$ - експертна бальна оцінка компанії- забудовника управляти ризиками, пов'язаними з ресурсами будівельних проектів;

$M_{a}$ - оцінка управління ризиками, пов'язаними 3 комунікаціями будівельних проектів, $a$ - кількісна оцінка здатності компанії-забудовника управляти ризиками, пов'язаними 3 комунікаціями проектів, $a=\overline{1 ; a^{\prime}}, a^{\prime}-$ експертна бальна оцінка компанії-забудовника управляти ризиками, пов'язаними 3 комунікаціями будівельних проектів;

$P_{z}$ - оцінка управління ризиками, пов'язаними із закупівлями будівельних проектів, $z$ - кількісна оцінка здатності компаніїзабудовника управляти ризиками, пов' язаними із закупівлями проектів, $z=\overline{1 ; z}$, $z^{\prime}$ - експертна бальна оцінка компаніїзабудовника управляти ризиками, пов'язаними із закупівлями будівельних проектів;

$H_{g}$ - оцінка управління ризиками, пов'язаними із стейкхолдерами будівельних проектів, $g$ - кількісна оцінка здатності компанії-забудовника управляти ризиками, пов'язаними із стейкхолдерами проектів, $g=\overline{1 ; g^{\prime}}, g^{\prime}-$ експертна бальна оцінка компанії-забудовника управляти ризиками, пов'язаними із стейкхолдерами будівельних проектів.

Обмеження цільової функції зрілості "Risk Management" компанії-забудовника представлені в табл. 3, а математична модель (1)-(10) набуває вигляду:

$$
\begin{gathered}
\Delta B_{R M}=\sum_{d}^{d^{\prime}} \sum_{i}^{i \prime} \sum_{u}^{u^{\prime}} \sum_{j}^{j \prime} \sum_{n}^{n^{\prime}} \sum_{m}^{m^{\prime}} \sum_{a}^{a \prime} \sum_{z}^{z^{\prime}} \sum_{g}^{g \prime}\left(I_{d}+\right. \\
+S_{i}+T_{u}+C_{j}+Q_{n}+R_{m}+M_{a}+ \\
\left.+P_{z}+H_{g}\right) \rightarrow o p t, \\
M_{I} \in S \cup T \cup C \cup Q \cup R \cup H, \\
\left\{\begin{array}{l}
M_{I I} \in A \cup S \cup T \cup C \cup Q \cup R \cup M \cup P \cup H, \\
M_{I I I} \in A \cup S \cup T \cup C \cup Q \cup R \cup M \cup P \cup H, \\
M_{I V} \in A \cup S \cup T \cup C \cup Q \cup R \cup M \cup P \cup H, \\
M_{V} \in A \cup S \cup T \cup C \cup Q \cup R \cup M \cup P \cup H .
\end{array}\right.
\end{gathered}
$$

Траєкторія розвитку зрілості ризикменеджменту компанії-забудовника матиме наступний вигляд:

$$
N \in M_{I} \cup M_{I I} \cup M_{I I I} \cup M_{I V} \cup M_{V} .
$$


Обмеження цільової функції зрілості “Risk Management” компанії-забудовника

\begin{tabular}{|l|c|c|c|c|c|}
\hline \multirow{2}{*}{$\begin{array}{c}\text { Управління ризиками, } \\
\text { пов'язаними з областями знань } \\
\text { проектного менеджменту }\end{array}$} & \multicolumn{5}{|c|}{ Рівні зрілості “Risk Management” } \\
\cline { 2 - 6 } & $\mathrm{I}\left(\mathrm{M}_{\mathrm{I}}\right)$ & $\mathrm{II}\left(\mathrm{M}_{\mathrm{II}}\right)$ & $\mathrm{III}\left(\mathrm{M}_{\mathrm{III}}\right)$ & $\mathrm{IV}\left(\mathrm{M}_{\mathrm{IV}}\right)$ & $\mathrm{V}\left(\mathrm{M}_{\mathrm{V}}\right)$ \\
\hline Управління інтеграцією (I) & 0 & 0,3 & 0,8 & 0,9 & 1 \\
\hline Управління змістом (S) & 0,25 & 0,5 & 0,8 & 0,9 & 1 \\
\hline Управління термінами (T) & 0,2 & 0,5 & 0,8 & 0,9 & 1 \\
\hline Управління вартістю (C) & 0,2 & 0,5 & 0,8 & 0,9 & 1 \\
\hline Управління якістю (Q) & 0,2 & 0,5 & 0,8 & 0,9 & 1 \\
\hline Управління ресурсами (R) & 0,2 & 0,5 & 0,8 & 0,9 & 1 \\
\hline Управління комунікаціями (M) & 0 & 0,3 & 0,8 & 0,9 & 1 \\
\hline Управління закупівлями (Р) & 0 & 0,3 & 0,8 & 0,9 & 1 \\
\hline Управління стейкхолдерами (H) & 0,25 & 0,5 & 0,8 & 0,9 & 1 \\
\hline
\end{tabular}

Оптимальний рівень зрілості ризикменеджменту компанії-забудовника визначається:

$$
o p t=\frac{\partial B_{R M_{\chi+1}}}{\partial B_{R M_{x}}}
$$

де $B_{R M_{x}}$ - складна організаційно-технічна система управління проектами і програмами компанії-забудовника, що знаходиться на х рівні зрілості з ризик-менеджменту;

$B_{R M_{x+1}}$ - складна організаційнотехнічна система управління проектами і програмами компанії-забудовника, що перейшла на наступний $(\mathrm{x}+1)$ рівень зрілості з ризикменеджменту.

Глобальний критерій розглядається як вимір зрілості компанії-забудовника 3 ризикменеджменту і визначається:

$$
M_{R M_{x}}=\sum_{\forall_{i}} \alpha_{i} \times v_{i},
$$

де $\alpha_{\mathrm{i}}-$ вагові коефіцієнти, $\boldsymbol{i}=\overline{\mathbf{1} ; \mathbf{9}}$, (9 - кількість областей знань управління проектами); $\forall_{i}$ - сума обмежень цільової функції зрілості $\mathrm{PMO}_{\mathrm{G}}$ (табл. 3).

Розроблені інструменти оцінювання зрілості ризик-менеджменту компаніїзабудовника $є$ важливими для удосконалення системи моніторингу i аналізу проектноорієнтованого (ризик-сталого) управління будівельними проектами. Застосування розробленого аналітичного інструментарію буде корисним у проектній діяльності будівельних та девелоперських компаній, а також структур капітального будівництва в органах міс- цевого самоврядування, які виконують будівельні проекти та програми. Авторський підхід потребує подальшого науковопрактичного розвитку у напрямі роботи 3 конкретними даними.

Висновки. Розроблено матрицю оцінки зрілості "Risk Management" в системі управління будівельними проектами (компаніїзабудовника), яка представлена характеристиками здійснення ризик-менеджменту. Встановлено, що застосування цієї моделі дозволить дирекціям компаній-забудовників і топменеджменту організацій, які реалізують будівельні проекти і програми, проводити самооцінку прогресу у розвитку управління ризиками проектів та обирати дії, необхідні для переходу на вищий рівень зрілості.

\section{Список літератури}

1. A Guide to the project management body of knowledge Construction (PMBOK® Guide). - USA: Project Management Institute, 2016. $489 \mathrm{p}$.

2. Рибак А. І. Азарова І. Б. Аналіз механізмів фінансування будівельних проектів в галузі житлового будівництва. Ринковий механізм фінансування. Управління розвитком складних систем. 2014. № 18. С. 88-97.

3. Данченко О. Б., Оберемок I. I., Донець О. М. Методи управління бюджетними ризиками при будівництві складних енергетичних об'єктів. Управління проектами та розвиток виробництва: 3б. наук. $n p$. Луганськ: вид-во СНУ ім. В. Даля, 2004. № 3 (11). C. 58-66. 
4. Ревякін О. В. Дослідження усунення негативного впливу виробничих ризиків на терміни реалізації будівельних проектів. Bicник Хмельнищького начіонального універcumemy, 2015. № 3. T. 3. С. 222-224.

5. Алтухов Д. В., Тугай О. А. Календарне планування в сучасних умовах. Шляхи niдвищення ефективності будівництва в умовах формування ринкових відносин, 2015. Вип. 34. С. 31-39.

6. Млодецький В. Р., Загуменнова А. В., Молошкіна Н. Ю. Концепція надійності в організації будівельного виробництва. Вісник ПДАБА, 2014. № 4. С. 19-24.

7. Азарова І.Б. Управління ризиками проектів у галузі житлового будівництва. Управління розвитком складних систем. 2015. № 23 (1). C. 11-20.

8. Фесенко Т. Г. Формування змісту портфеля інвестиційно-будівельних проектів. Вісник Наџіонального технічного університету «ХПI». Збірник наукових праџь. Серія : Стратегічне управління, управління портфелями, програмами та проектами. Х. : НТУ «ХПІ». 2014. № 2 (1045). С. 45-52. DOI: 10.20998/2413-3000.2014.1045.8.

9. Сєріков А. В. Семенова Г. І. Креативне управління ризиками - важлива проблема Українського девелопменту. Економіка будівництва і міського господарства. 2008. Том. 4. № 3. C. 137-144.

10.Фесенко Т. Г., Мохамед Абдулсалам Сієк Алі. Ризик-менеджмент в контексті моделі зрілості управління будівельними проектами. Управління проектами розвитку суспільства. Тема: «Управління проектами в умовах переходу до поведінкової економіки»: тези доповідей / відn. за випуск С. Д. Бушуєв. Київ: КНУБА, 2018. С. 217220.

11.Kerzner H. Strategic planning for project management using a project management maturity model. New York: John Wiley \& Sons, 2001. 256 p.

\section{References}

1. A Guide to the project management body of knowledge Construction (PMBOK® Guide) (2016) USA: Project Management Institute, 489.

2. Rybak, A. I., Azarova, I. B. (2014) Analiz mekhanizmiv finansuvannya budivel'nykh proektiv $\mathrm{v}$ haluzi zhytlovoho budivnytstva. Rynkovyy mekhanizm finansuvannya [Analysis of mechanism soffinancing of buildpro jectsinarea of housing building. Market mechanism of financing]. Management of Development of Complex Systems, No. 18, pp. 88-97.

3. Danchenko, O. B., Oberemok, I. I., Donec, O. M. (2004) Metody upravlinnya byudzhetnymy ryzykamy pry budivnytstvi skladnykh enerhetychnykh ob'yektiv [Methods of budget risk management in building complex power objects]. Project management and production development, No. $3(11)$, pp. 58-66.

4. Reviakin, V. O. (2015). Doslidzhennya usunennya nehatyvnoho vplyvu vyrobnychykh ryzykiv na terminy realizatsiyi budivel'nykh proektiv [Research elimination of the negative impact of production risks in terms of implementation of construction projects]. Visnyk Khmel'nyts'koho natsional'noho universytetu [Bulletin of the Khmelnytsky National University], No. 3(3), pp. 222-224.

5. Altukhova, D. V., Tugay, O. A. (2015) Kalendarne planuvannya $\mathrm{v}$ suchasnykh umovakh [Scheduling in modern conditions]. Shlyakhy pidvyshchennya efektyvnosti budivnytstva $v$ umovakh formuvannya rynkovykh vidnosyn [Ways of increasing the efficiency of construction in conditions of formation of market relations], No. 34, pp. 31-39.

6. Mlodets'kyy, V. R., Zahumennova, A. V., Moroshkina, N.Yu. (2014) Kontseptsiya nadiynosti $\mathrm{v}$ orhanizatsiyi budivel'noho vyrobnytstva [Concept of reliability in organization of construction production]. Visnyk PDABA [Bulletin of the Pridneprovsk Academy of Civil Engineering and Architecture], No. 4, pp 19-24.

7. Azarova, I. (2015). Upravlinnya ryzykamy proektiv u haluzi zhytlovoho budivnytstva [Risk management of project in housing building]. Management of Development of Complex Systems, No. 23, pp. 11-20.

8. Fesenko, T. G. (2014). Formuvannya zmistu portfelya investytsiyno-budivel'nykh proektiv [Formation of the contents of a portfolio of investment and construction projects]. Visnyk Natsional'noho tekhnichnoho universytetu «KHPI». Zbirnyk naukovykh prats'. Seriya : Stratehichne upravlinnya, upravlinnya port- 
felyamy, prohramamy ta proektamy [Bulletin of the National Technical University "KhPI". Series: Strategic Management, Portfolio Management, Programs and Projects], No. 2 (1045), pp. 45-52. doi: 10.20998/24133000.2014.1045.8.

9. Syerikov, A. V., Semenova, H. I. (2008). Kreatyvne upravlinnya ryzykamy - vazhlyva problema Ukrayins'koho developmentu [Creative risk management is an important issue of Ukrainian development]. Ekonomika budivnytstva i mis'koho hospodarstva [Economics of construction and municipal economy], No. 4(3), pp. 137-144.

10.Fesenko, T. G., Mohamed Addulsalam Seek Ali (2018). Ryzyk-menedzhment v konteksti modeli zrilosti upravlinnya budivel'nymy proektamy [Risk management in the context of the model of maturity management of construction projects]. Upravlinnya proektamy rozvytku suspil'stva. Tema: "Upravlinnya proektamy $v$ umovakh perekhodu do povedinkovoyi ekonomiky»: tezy dopovidey [Management of community development projects. Topic: "Project Management in the Transition to a Behavioral Economy": Abstracts of Reports], Kyiv: KNUBA, pp. 217220.

11.Kerzner, H. (2001). Strategic planning for project management using a project management maturity model. New York: John Wiley \& Sons, 256.

T. G. Fesenko ${ }^{1}$, Candidate of Technical Sciences, $P h D$, Professor, Department of Engineering and Architecture, e-mail: fesenkotatyana@gmail.com

Mohamed Addulsalam Seek $\mathrm{Ali}^{2}, \mathrm{PhD}$-student,

${ }^{1}$ Luhansk National Agrarian University, Alchevskykh str., 44, Kharkiv, 61002, Ukraine

${ }^{2}$ Institution of higher education University of Economics and Law KROK Tabirna st., 30-32, Kyiv, 03113, Ukraine,

\section{MODELING OF “RISK MANAGEMENT” ASSESSMENT IN THE CONSTRUCTION PROJECT MANAGEMENT SYSTEM}

The basic processes, methods and tools of the project risk management in the knowledge system "Guide to the Project Management Body of Knowledge" outlined. The theoretical and practical approaches to managing risk events affecting the cost, terms, quality of construction projects analysed. The correlation matrix of risk management processes to "tools and methods" of their implementation compiled.

It is proposed to highlight the risk components as an important condition for the developer's technological maturity in construction projects, programs, portfolio management. The risk management maturity model for the context of construction project risk management is developed. The mathematical description for the evaluation of five maturity levels of risk management presented. The restrictions of the target function of maturity "Risk Management" for each of the levels defined.

The developed assessment tool is applicable for the work of top management of construction and development companies. It will be useful to self-assess progress in the development of risksustainable management. It is effective in choosing the actions necessary to move to a higher level of maturity. It is noted that the author's approach requires further scientific and practical development in the direction of operations with specific data.

Keywords: risk management maturity, construction project management, construction developer company.

Стаття надійшла 17.05.2018.

Реиензенти: О. Б. Данченко, д.т.н., доиент,

О. В. Коломицева, д.е.н., професор. 